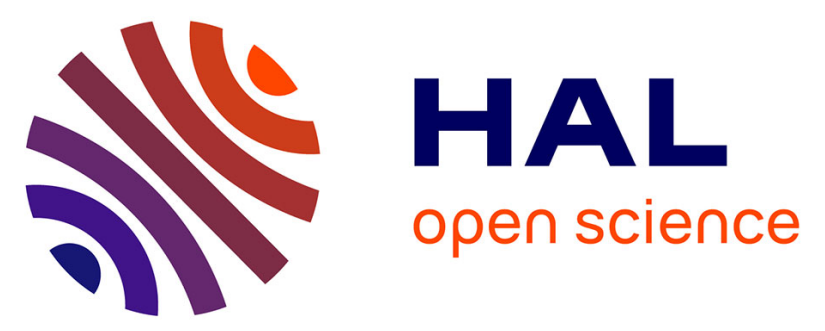

\title{
Investigating physical processes leading to sinkhole occurrence in Val d'Orléans (France)
}

Jérôme Perrin, Sylvain Pasquier, Alexis Gutierrez, Damien Salquebre, Emilie

Vandoudheusden, Emmanuelle Joigneaux, Christophe Chateau, Audrey

Guirimand-Dufour, Nevila Jozja, Christian Défarge, et al.

\section{To cite this version:}

Jérôme Perrin, Sylvain Pasquier, Alexis Gutierrez, Damien Salquebre, Emilie Vandoudheusden, et al.. Investigating physical processes leading to sinkhole occurrence in Val d'Orléans (France). EuroKarst 2016, Sep 2016, Neuchatel, Switzerland. 8 p. hal-01355612

\section{HAL Id: hal-01355612 https://hal-brgm.archives-ouvertes.fr/hal-01355612}

Submitted on 23 Aug 2016

HAL is a multi-disciplinary open access archive for the deposit and dissemination of scientific research documents, whether they are published or not. The documents may come from teaching and research institutions in France or abroad, or from public or private research centers.
L'archive ouverte pluridisciplinaire HAL, est destinée au dépôt et à la diffusion de documents scientifiques de niveau recherche, publiés ou non, émanant des établissements d'enseignement et de recherche français ou étrangers, des laboratoires publics ou privés. 


\title{
Investigating physical processes leading to sinkhole occurrence in Val d'Orléans (France)
}

\author{
Jérôme Perrin a, Sylvain Pasquier ${ }^{\text {a,b }}$, Alexis Gutierrez ${ }^{a}$, Damien Salquèbre ${ }^{c}$, \\ Emilie Vandoudheusden ${ }^{d}$, Emmanuelle Joigneaux ${ }^{\mathrm{e}}$, Christophe Château ${ }^{\mathrm{e}}$, \\ Audrey Guirimand-Dufour ${ }^{b}$, Nevila Jozja ${ }^{b}$, Christian Défarge ${ }^{b, f}$, Stéphane \\ Binet $^{\mathrm{f}}$

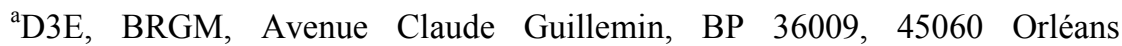 \\ [Je.perrin@brgm.fr]

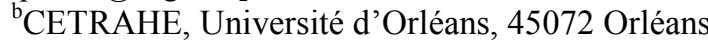 \\ ${ }^{c}$ DAT-Centre, BRGM, Avenue Claude Guillemin, BP 36009, 45060 Orléans \\ ${ }^{\mathrm{d} D A T}$-Auvergne, BRGM, 12 avenue des Landais, 63170 Aubière \\ ${ }^{\text {e}}$ DSA Technologies, 595 rue de la Goudronnerie, 45400 Semoy \\ 'ISTO, CNRS - Université d'Orléans - BRGM, 45071 Orléans
}

\begin{abstract}
Sinkholes in Val d'Orléans occur regularly and can have significant socio-economic impacts. They are due to the presence of a karstified limestone under $5-15 \mathrm{~m}$ thick alluvial deposits. Intense karstification within the area is caused by infiltration of large amount of Loire River water in the karst aquifer through swallow holes. Two mechanisms for the formation of sinkholes are proposed: 1) suffosion of alluvial deposits towards the karstic conduits leading to the occurrence of a void at the base of the alluvium that will progressively enlarge up to reach the surface; 2) karst conduit ceiling breakdown as a consequence of conduit size evolution and/or hydrostatic pressure changes within the karst aquifer.

In order to better understand the mechanisms leading to sinkhole occurrence, an experimental site comprising groundwater and surface deformation monitoring has been setup in an area known to be regularly impacted by new sinkholes.

First results show similar groundwater level variations in the alluvial and karstic aquifers with however a small difference at the beginning of recession limbs when the alluvial aquifer shows higher water levels compared to the karstic aquifer. This situation may favour suffosion and/or sloughing. The comparison of water chemistry between Loire River and karst groundwater seems to indicate very active dissolution processes directly downgradient of the swallow holes and a potential rapid evolution of karst conduit sizes. Such an evolution can contribute to conduit ceiling breakdown resulting in collapse sinkholes.

Obtained results bring new insights that will be useful for adequate sinkhole risk management (e.g., hazard mapping, surveillance methodology, etc.).
\end{abstract}

\section{Introduction}

A geological hazard specific to karst regions is ground subsidence caused by the presence of voids in soluble rocks as a result of dissolution. In limestone karst 
settings, subsidence likelihood becomes especially significant when limestone is covered (mantled or buried karst) (e.g., Waltham et al. 2005). Sinkholes result from different processes (Waltham et al. 2005, Ford and Williams 2007): dissolution sinkholes and collapse sinkholes occur in barren karst, dropout and suffosion sinkholes occur in mantled karst, and subsidence/compaction sinkholes occur in buried karst.

However the detailed physical processes leading to the appearance of sinkholes remain still partly unknown despite several lab (Lei et al. 2002, Jiang et al. 2015, Sato \& Kuwano 2015) or modelling (Tharp 1999, 2002) studies, and as a consequence methodologies devoted to sinkhole appearance monitoring are still in their infancy: when water table decline is the dominant triggering factor, groundwater level monitoring can be setup (e.g., Lei et al. 2002, Yao et al. 2007); in case of other triggering factors, optical fibre monitoring in the overburden may be able to detect small deformation before the collapse occurrence (e.g., Lanticq et al. 2009, Jiang et al. 2006, Meng et al. 2013); in addition, ground surface deformation radar monitoring (GB-InSAR) is presented by Intrieri et al. (2015).

The present study focuses on physical processes leading to sinkhole in mantled karst setting through monitoring both groundwater parameters in the aquifers and surface deformation within a dedicated experimental site. Perspectives of this study are to identify potential methods for sinkhole appearance prevention (e.g., pre-event indicators monitoring).

The experimental site was setup in the mantled karst of Val d'Orléans located $120 \mathrm{~km}$ south of Paris (Figure 1). This area was chosen because sinkhole occurrence is frequent and this geological hazard is highly significant locally as it regularly impacts infrastructures such as buildings, roads or river embankments. Thierry et al. (2005) used different geophysical investigations to characterise the geohazard constituted by shallow karst conduits in the urbanised part of the Val d'Orléans. In the same area, the risk associated with the presence of karst conduits under Loire River embankments and potential sinkhole occurrence beneath these structures has been assessed by geophysics (Samyn et al. 2014) and by a geotechnical characterisation (Gombert et al. 2015).

The karstic formation is constituted by the Beauce limestone, a Tertiary lacustrine limestone of $200 \mathrm{~m}$ maximum thickness made up of two members (Pithiviers and Etampes) separated by marls (Molasse du Gâtinais) (Maget and Pointet 2006). The upper Pithiviers member is the main karstified formation. The overlying formations are constituted by Quaternary alluvial deposits (Holocene) of the Loire River which are mostly permeable and constitute an unconfined aquifer (Figure 1).

Fig. 1. Simplified geological map of the study area and geological cross-section (modified from Caudron 1964). Dropout and collapse sinkholes are indicated by red circles and Bouillon spring (main spring of the karst system) by a blue circle. 
The active karst aquifer is dominated by numerous swallow holes observed along the Loire River and tributaries upstream of Orléans city (Lepiller 2006) (Figure 1). Total water losses from the Loire to the aquifer are estimated between 15 and $20 \mathrm{~m}^{3} / \mathrm{s}$. New attempt at quantifying the water losses, using 46 years of data, seem to give a lower value, with an average of $11.5 \mathrm{~m}^{3} / \mathrm{s}$ (Gutierrez \& Binet 2012). This water is brought back to the Loire River by several springs starting from Orléans city among which the most important one (Bouillon spring) is at the origin of Loiret River (Figure 1). The hydrogeology of the karst aquifer and its main springs has been studied by Albéric \& Lepiller (1998), Joodi et al. (2010), and Joigneaux et al. (2011).

Two mechanisms for the formation of sinkholes are proposed (Gombert et al. 2015, Perrin et al. 2016): 1) suffosion of alluvial deposits towards the karstic conduits leading to the occurrence of a cavity at the base of the alluvium that will progressively enlarge up to reach the surface (dropout sinkhole); 2) karst conduit ceiling breakdown as a consequence of conduit size evolution and/or hydrostatic pressure changes within the karst aquifer (collapse sinkhole).

\section{Main results}

\section{Site characterisation}

Three boreholes ( 2 in limestone, 1 in alluvium) were drilled for setting up piezometers. The two holes in the limestone (Pz1, Pz3bis) encountered an active karst conduit about $8 \mathrm{~m}$ below the limestone top. A video inspection in Pz1 indicates that the conduit is slightly elongated along the horizontal plane and has a maximum height of $70 \mathrm{~cm}$ and width of at least $1 \mathrm{~m}$; the size of Pz3bis conduit may be slightly higher ( $1 \mathrm{~m}$ drill bit drop estimated during drilling operations). When these two boreholes are pumped, most if not all the water comes from the karst conduits. While drilling Pz3bis, a loose formation about $50 \mathrm{~cm}$ thick was encountered $3 \mathrm{~m}$ below the active conduit associated with production of highly turbid water. This level is interpreted as a partly clogged conduit. The flow connection between Loire swallow-holes and conduits intercepted by the boreholes was proven by temperature and EC well logging showing values close to the ones observed in the river at depths corresponding to the conduits and by a tracer test (Figure 2). This test was conducted under medium-flow conditions (12/09/14): $2 \mathrm{~kg}$ of naphtionate was injected directly in a swallow hole located $750 \mathrm{~m}$ upgradient of the experimental site and in the river bed about $10 \mathrm{~m}$ away from the southern bank. Pz1 was pumped at a discharge of $40 \mathrm{~m}^{3} / \mathrm{h}$ and samples were taken at the pump outlet; Pz3bis was sampled using a small pump. Samples were analysed in the lab using a spectrofluorimeter (HITACHI F-7000). Breakthrough curves were observed at the two piezometers (Figure 2), indicating that the conduits are fed by 
a same swallow hole. Breakthrough in Pz3bis showed lower maximum concentration and larger times for first arrival and at peak concentration resulting in maximum tracer velocity of 172 and $222 \mathrm{~m} / \mathrm{h}$ and mean velocity at peak concentration of 83 and $123 \mathrm{~m} / \mathrm{h}$ for Pz3bis and Pzl respectively. These differences may be partly caused by pumping at Pzl; however pumping rate was low in comparison to the natural flow rate in the conduit and it is thus believed that the effect of pumping on natural flow paths remained minimal. It is more likely that breakthrough differences were caused by the hydraulic characteristics of the two conduits (flow rates in the conduits, tortuosity, connections with other tributaries, etc.). The tracer recovery cannot be estimated precisely because the actual flux in both conduits is unknown; however if we maximise this flux $\left(400 \mathrm{~m}^{3} / \mathrm{h}\right.$ in each conduit corresponding to a section of $2 \mathrm{~m}^{2}$ and a velocity of $200 \mathrm{~m} / \mathrm{h}$ ), recovery would only be about $5 \%$, which makes the existence of additional traced conduits likely.

Additional tracer tests between the piezometers showed that there is no direct connections between the conduit of Pz1 and the one of Pz3bis although their elevation is identical (about $15 \mathrm{~m}$ below the Loire level during low water), thus indicating that they are two distinct branches connected to the same network. $\mathrm{NaCl}$ injected in Pz2bis (alluvium) while a pumping test was carried out in Pz1 was slowly released in the alluvial aquifer over two days before reaching background concentrations as shown by continuous monitoring of EC, thus indicating no direct flux between the two aquifers.

Fig. 2. On top: local map showing the tracer injection point (swallow-hole) and the monitored piezometers. Tracer breakthrough curves (bottom left) and temperature well logging in Pz3bis (bottom right): the blue rectangle indicates the active conduit location; on 30/6/15, the Loire river temperature was $28.7^{\circ} \mathrm{C}$ (temperature not known for the other date, but likely around $23-25^{\circ} \mathrm{C}$ ).

The pumping test in Pz1 during the tracing experiment did neither influence Pz2bis nor Pz3. Interpretation of Pz1 drawdown led to a transmissivity of $0.2 \mathrm{~m}^{2} / \mathrm{s}$. A slug test in Pz2bis led to a hydraulic conductivity of $1.4 \times 10^{-6} \mathrm{~m} / \mathrm{s}$; these results illustrate the high permeability contrast between both aquifers.

During drilling, total loss of circulation was observed at the top of the limestone indicating a high permeability level, which is interpreted as a weathered limestone zone also visible on the electrical tomography profiles carried out before drilling (lower resistivity layer above more resistive limestone unit). These results from drilling, logging, and tracing experiments are summarised in a hydrogeological cross-section (Figure 3). Also the river water level and groundwater level are represented for both low and high flow conditions. It should be noted that the river water level presents higher heads at all times ( $2.2 \mathrm{~m}$ difference at low stage) but the head difference decreases under high flow conditions. The amplitude of water level fluctuations is quite high and reaches $4.2 \mathrm{~m}$ for groundwater and $3.5 \mathrm{~m}$ for the Loire river during the observation period (Sept. 2014-Dec. 2015). 
Fig. 3. Experimental site hydrogeological cross-section showing the three piezometers (Pz1, Pz2bis, Pz3bis) and surface water and groundwater levels (light blue during flood events; dark blue during low water).

\section{Water level fluctuations}

Piezometric levels both in the alluvial and karstic aquifers are subdued to the Loire river levels, which acts as a head boundary in the local hydrogeologic system (Figure 4). On flood falling limbs, we notice a slight head difference between the two aquifers, with higher water levels in the alluvium. Maximum difference is about $10 \mathrm{~cm}$. It seems that this difference occurs only during floods at higher water levels (winter season). During the large recession occurring in spring 2015, a small sinkhole located $20 \mathrm{~m}$ north of Pz1 $(2 \times 1 \mathrm{~m}$ in diameter $)$ became $3 \mathrm{~cm}$ deeper (total depth increased from 18 to $21 \mathrm{~cm}$ ) as shown by monthly ground surveys using a laser levelling device. Later on, no movement was observed. Periods when hydraulic heads are higher in the alluvial aquifer are favourable to suffosion because groundwater fluxes are orientated from the alluvium towards the karst aquifer. This slight ground movement observed during such a hydraulic period may indicate that suffosion process occurred. However, it remains hypothetical at this stage and additional data is needed for confirmation.

Another process leading to the occurrence of collapse sinkhole is hydraulic fracturing at the walls of pre-existing voids located within the overburden at the contact with the rock head; this mechanism occurs when pore pressure gradient exceeds normal stress gradient (Tharp 1999, 2002). Such situation favours sloughing of the soil towards the pre-existing void and its progressive enlargement (upward propagation) followed by collapse. In the local context, high pore pressure gradient prevails when water table decrease will lead the lower part of the alluvium from saturated to unsaturated conditions; the situation may become even more critical when water table drops below the rock head (total loss of buoyant support in the alluvium).

Fig. 4. Piezometric variations recorded at the three piezometers (Pz1, Pz2bis, Pz3bis), Loire river water levels recorded in Orléans (15 km downstream of experimental site) and daily rainfall recorded at Orléans meteorological station. The dashed-lined rectangle indicates the period when a small depression monitored at the site became deeper. 


\section{Dissolution process}

In order to appraise the evolution of dissolution-related parameters from the Loire river swallow holes to the conduits at the experimental site (750 m downgradient) and the major conduit outlet (Bouillon spring, $13 \mathrm{~km}$ downgradient of the swallow holes), six sampling campaigns were carried out covering different hydrological conditions. Except in September 2014 and June 2015, samples were collected the same day, thus Bouillon spring water is not directly comparable in all cases to the ones collected upgradient because water travel time is 3-4 days, however the difference in water chemistry can be considered minimal especially under stable flow conditions. Results for calcium concentrations obtained by ion chromatography (DIONEX ICS 1100; Figure 5) show that the Loire water is the most dilute at all times. The Bouillon spring water is enriched in calcium compared to Loire water by $0.16-0.45 \mathrm{mmol} / \mathrm{L}$. The difference is similar to the one given by Binet et al. (2010), who found an increase of $0.25 \mathrm{mmol} / \mathrm{L}$ based on over 100 analyses and also to the range of 0.07-0.29 $\mathrm{mmol} / \mathrm{L}$ given by Albéric \& Lepiller (1998) who took into account the 3 days lag between Loire and Bouillon. This calcium increase is attributed to limestone dissolution by Albéric \& Lepiller (1998) and Binet et al. (2010). The new data from the experimental site show different features: Pz3bis is enriched in calcium compared to Pz1 under high flow conditions (May 2015 \& January 2016); the higher value observed in September 2014 is likely due to water pumping above the conduit in Pz3bis, thus not representative of conduit water. Except for the differences explained above, conduit water at the experimental site exhibit calcium concentrations similar to the ones measured at Bouillon spring. Concentrations are even higher early June 2015, however this difference may be caused by the hydrodynamic conditions (falling limb of a flood). Such results indicate that intense dissolution occurs directly downgradient of the swallow holes. Reasons for this are still unclear, but it is possibly caused by a boost in groundwater dissolution potential as a result of oxidation of organic matter issued from the river (Albéric et Lepiller 1998). This intense dissolution may induce rapid enlargement of conduit sizes in the vicinity of swallow holes $(1 \mathrm{~cm} /$ year as an order of magnitude estimate for an initial $1 \mathrm{~m}$ radius circular conduit). This evolution can consequently cause ground instability (i.e., appearance of collapse sinkholes). This potentially rapid evolution of conduit diameter was already proposed by Binet et al. 2010. Apart from consequences on collapse hazard, it can also affect the aquifer hydrodynamics (e.g., temporal changes in transmissivities).

Fig. 5. Calcium concentrations measured in the Loire river near swallow holes, in the karst conduits of the experimental site (Pz1, Pz3bis), and at Bouillon spring. 


\section{Conclusions and perspectives}

The results of this study are preliminary: they show that dissolution processes are very active directly downgradient of the swallow holes fed by the Loire river; this rapid dissolution may play a role in the occurrence of collapse sinkhole and more generally on the karstic aquifer hydrodynamics. Dropout sinkholes by suffosion process alone cannot be ruled out, however first results show that the head difference between the two aquifers remains small and vertical flow velocity may not be sufficient for suffosion to occur at least in part of the study area. Another process that may also contribute to internal erosion and appearance of dropout sinkhole is the plurimetric water table fluctuations that occur across the limestone-alluvium interface and associated pore pressure transients known to favour sloughing.

Future studies should enable to obtain more precise data and information on the dominant processes leading to sinkhole occurrence and thus to improve our predictive capacity. In parallel, low-cost deformation sensors have been developed during the project and are presently tested onsite. Such devices are likely the most promising surveillance method so far for anticipating sinkhole occurrence in sensitive areas.

\section{Acknowledgments}

This work was financially supported by "Conseil Départemental du Loiret". The authors are grateful to Mrs. De Chalus, Mr. Trassebot and Mr. Delahaye for the access to the site and their help, to the Parc floral d'Orléans for access to the Bouillon spring, and to Renata Zocatelli (CETRAHE) for help in ion analysis.

\section{References}

Albéric P., Lepiller M. 1998. Oxidation of organic matter in a karstic hydrologic unit supplied through stream sinks (Loiret, France). Water Research 32: 2051-2064.

Binet S., Joodi A., Joigneaux E., Albéric P., Gutierrez A. 2010. Localisation of a Reactive Transport Zone in a Saturated Karstic Conduit Deduced from Natural and Artificial Tracer Tests. Advances in Research in Karst Media. B Andréo (Eds), Springer: 123-129.

Ford D., Williams P. 2007. Karst hydrogeology and geomorphology. John Wiley \& Sons Ltd, England.

Gombert P., Orsat J., Mathon D., Alboresha R., Al Heib M., Deck O. 2015. Rôle des effondrements karstiques sur les désordres survenus sur les digues de Loire dans le Val d' Orléans (France). Bulletin of Engineering Geology and the Environment 74, pp. 124-140.

Intrieri E., Gigli G., Nocentini M., Lombardi L., Mugnai F., Fidolini F., Casagli N. 2015. Sinkhole monitoring and early warning: An experimental and successful GB-InSAR application. Geomorphology 241: 304-314.

Jiang X.Z., Lei M.T., Chen Y.,Ge J. 2006. An experiment study of monitoring sinkhole collapse by using BOTDR optical fiber sensing technique. Hydrogeology and Engineering Geology 33. $6: 75-79$. 
Jiang F., Lei M., Jiang-ling D. 2015. Study on the critical velocity of groundwater to form subsidence sinkholes in a karst area. 14th Sinkhole conference, NCKRI Symposium 5: 531-536

Joodi, A. S., Sizaret, S., Binet, S., Bruand, A., Alberic, P., \& Lepiller, M. 2010. Development of a darcy-brinkman model to simulate water flow and tracer transport in a heterogeneous karstic aquifer (Val d'Orléans, France). Hydrogeology Journal, 18(2), 295-309. doi:http://dx.doi.org/10.1007/s10040-009-0536-x

Joigneaux, E., Alberic, P., Pauwels, H., Page, C., Terray, L., \& Bruand, A. 2011. Impact of climate change on groundwater point discharge: Backflooding of karstic springs (Loiret, France). Hydrology and Earth System Sciences, 15(8), 2459-2470.

Lanticq V., Bourgeois E., Magnien P., Dieleman L., Vinceslas G., Sang A., Delepine-Lesoille S. 2009. Soil-embedded optical fiber sensing cable interrogated by Brillouin optical timedomain reflectometry (B-OTDR) and optical frequency-domain reflectometry (OFDR) for embedded cavity detection and sinkhole warning system. Measurement science \& technology 20(3). DOI: 10.1088/0957-0233/20/3/034018

Lei M.T., Jiang X.Z., Li Y. 2002. New advances in karst collapse research in China. Environmental Geology 42 (5): 462-468.

Lepiller M., 2006 : Val d'Orléans. In : Aquifères et eaux souterraines en France, tome 1, J.-C. Roux (éd.), BRGM Éditions, 200-214.

Maget P., Pointet T., 2006 : Beauce. In : Aquifères et eaux souterraines en France, tome 1, J.-C. Roux (éd.), BRGM Editions, 191-199.

Meng Y., Dai J., Jia L., Lei M., Ji F. 2013. Typical methods for forecasting karst collapse in China. National Cave and Karst Research Institute (NCKRI) Symposium 2: 239-245.

Perrin Je., Gutierrez A., Vanoudheusden E., Salquèbre D., Joigneaux E., Château C., N. Jozja, Défarge C., Binet S. 2016. Projet i-Fontis : vers une méthodologie de surveillance de l'apparition de fontis dans le Val d'Orléans. Rapport final. BRGM/RP- 65474-FR, 82 p.,

Samyn, K., Mathieu F., Nachbaur, A., Closset L. 2014. Integrated geophysical approach in assessing karst presence and sinkhole susceptibility along flood-protection dykes of the Loire River, Orléans, France. Engineering Geology 183: 170-184.

Sato M., Kuwano R. 2015. Suffusion and clogging by one-dimensional seepage tests on cohesive soil. Soils and Foundations. http://dx.doi.org/10.1016/j.sandf.2015.10.008

Tharp, T.M., 1999. Mechanics of upward propagation of cover-collapse sinkholes. Engineering Geology 52, 23-33.

Tharp, T.M., 2002. Poroelastic analysis of cover-collapse sinkhole formation by piezometric surface drawdown. Environmental Geology 42, 447-456.

Thierry, P., Debeblia, N., \& Bitri, A. 2005. Geophysical and geological characterisation of karst hazards in urban environments; application to orleans (france). Bulletin of Engineering Geology and the Environment, 64(2), 139-150. doi:http://dx.doi.org/10.1007/s10064-004-0247-4

Yao C.M., Feng K.Y., Wang Y.B., Wang X.Y., Ren C.A. 2007. Application of numerical modeling of groundwater flow to the construction of early-warning system of karst collapse: Exemplified by the karst collapse in the Linyi urban area. Hydrogeology and Engineering Geology 34.4: 94-97, 102

Waltham A.C., Bell F.G., Culshaw M.G. 2005. Sinkholes and Subsidence: karst and cavernous rocks in engineering and construction. Praxis Publishing Ltd, Chichester, UK : 382 p. 